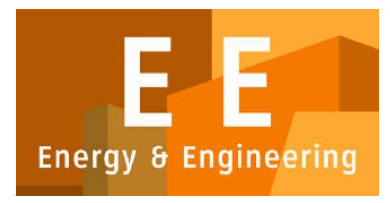

PAPER - OPEN ACCESS

\title{
Penataan Ruang Tepi Air Untuk Pengembangan Kawasan Ekowisata Di Tano Ponggol
}

\author{
Author : Widya Muhammad Tri Yudha dan Dwira Nirfalini Aulia \\ DOI $\quad: 10.32734 /$ ee.v2i1.423 \\ Electronic ISSN $\quad: 2654-704 X$ \\ Print ISSN $\quad: 2654-7031$
}

Volume 2 Issue 1 - 2019 TALENTA Conference Series: Energy \& Engineering (EE)

\section{(ㅇ) $(19$}

This work is licensed under a Creative Commons Attribution-NoDerivatives 4.0 International License.

Published under licence by TALENTA Publisher, Universitas Sumatera Utara 


\title{
tolenthilh hion TALENTA Conference Series
}

Available online at https://talentaconfseries.usu.ac.id

\section{Penataan Ruang Tepi Air Untuk Pengembangan Kawasan Ekowisata Di Tano Ponggol}

\author{
Widya Muhammad Tri Yudha ${ }^{\mathrm{a}}$, Dwira Nirfalini Aulia ${ }^{\mathrm{a}, \mathrm{b}, *}$ \\ ${ }^{a}$ Magister Teknik Arsitejtur, Fakultas Teknik, Universitas Sumatera Utara \\ ${ }^{b}$ Departemen Arsitektur, Fakultas Teknik, Universitas Sumatera Utara \\ wmt_yudha@yahoo.com,dwira_aulia@yahoo.com
}

\begin{abstract}
Abstrak
Tano Ponggol merupakan sebuah kawasan di kecamatan Pangururan pulau Samosir, yang berada di daerah wisata Geopark Danau Toba, dimana tanahnya dipenggal menjadi sebuah kanal yang kedua ujungnya mengarah ke Danau Toba dan kemudian memisahkan Pulau Samosir dengan daerah sekitarnya. Pada kanal ini kemudian dibangun sebuah jembatan penghubung kembali ke pulau Samosir. Menurut pengamatan, pada saat ini Tano Ponggol mengalami degradasi kualitas ruang dimana aktivitas kawasan hanya bersifat fungsional, yaitu jalur penghubung saja. Kawasan ini memiliki kondisi yang tidak sesuai dengan rencana induk pengembangan pariwisata daerah yang berencana mengembangkan kawasan ini menjadi sebuah kawasan ekowisata. Oleh karena itu, tulisan ini bertujuan untuk mendukung program pemerintah dalam mengembangkan Tano Ponggol menjadi sebuah kawasan ekowisata dengan cara melakukan penataan ruang tepi air di sepanjang kanal dan jembatan tersebut. Penataan ruang tepi air ini dilakukan dengan cara merevitalisasi kawasan melalui penyuntikan beberapa fungsi baru yang akan dikonsepsikan melalui analisa karakter, potensi, dan permasalahan kawasan di tano Ponggol. Penelitian ini diharapkan dapat berkontribusi dalam memberikan solusi berupa pedoman pengembangan sebuah kawasan ekowisata tepi air pada sebuah daerah geopark, dalam hal ini khususnya bagi pemerintah Kabupaten Samosir dalam mengembangkan kawasan ekowisata tepi air di Tano Ponggol. Hasil dari penelitian ini berupa kriteria desain yang ideal dan simulasi perancangan.
\end{abstract}

Kata Kunci: penataan ruang tepi air; ekowisata; geopark; ekowisata tepi air

\begin{abstract}
Tano Ponggol is an area in Pangururan sub-district, Samosir Island, which is located in the Geopark tourism area of Lake Toba, where the land is decapitated into a canal which ends towards Lake Toba and then separates Samosir Island from the surrounding area. On this canal, a connecting bridge was built back to Samosir island. According to observations, at this time Tano Ponggol is experiencing degradation in the quality of space where regional activities are only functional, namely connecting lines just. This area has conditions that are not by the regional tourism development master plan that plans to develop this area into an ecotourism area. Therefore, this paper aims to support the government program in developing Ponggol Tano into an ecotourism area by conducting spatial planning of the water along the canals and bridges. This waterfront spatial arrangement is carried out by revitalizing the area through injecting several new functions that will be conceptualized through analysis of the character, potential, and regional problems in Ponggol. This research is expected to contribute in providing solutions in the form of guidelines for developing a waterfront ecotourism area in a geopark area, in this case especially for the Samosir Regency government in developing waterfront ecotourism areas in Tano Ponggol. The results of this study are the ideal design criteria and design simulations.
\end{abstract}

Keywords: waterfront spatial planning; ecotourism; Geopark; waterfront ecotourism

\section{Pendahuluan}


Tano Ponggol terletak di Kelurahan Siogungogung, Kecamatan Pangururan, Kabupaten Samosir, Provinsi Sumatera Utara. Kabupaten Samosir terletak di area Geopark Danau Toba. Danau toba merupakan danau terbesar di Indonesia dan danau vulkanik terbesar dunia yang terbentuk dari kaldera letusan gunung Toba. Geopark memiliki kepentingan internasional sehingga ada kebijakan yang harus dijalankan didalamnya. Oleh karena pada umumnya Geopark mempromosikan kesadaran akan bahaya geologis yang dapat terjadi di muka bumi, dalam hal ini adalah gunung merapi, maka warisan geologinya harus dikonservasi dan digunakan secara berkelanjutan. Selain itu, Geopark juga mewajibkan peningkatan ekonomi penduduk yang tinggal di dalamnya. Kebijakan ini menjadi salah satu kriteria pada perencanaan kawasan di Tano Ponggol.

Tano Ponggol berada di kecamatan Pangururan yang merupakan ibukota kabupaten Samosir dimana didalamnya terdapat pusat pemerintahan kabupaten Samosir. Kawasan ini pada awalnya merupakan sebuah area darat yang kemudian tanahnya dipenggal dan menjadi sebuah kanal. Tano Ponggol dibentuk oleh Belanda untuk memisahkan pulau Samosir dengan kawasan sekitarnya. Tano Ponggol dibangun oleh Belanda dengan tujuan salah satunya yaitu untuk kelancaran transportasi air. Tano Ponggol juga merupakan gerbang utama jalur darat menuju pulau Samosir. Sebagai gerbang utama, Tano Ponggol merupakan salah satu destinasi wisata di pulau Samosir. Kondisi geografis ini yang pada akhirnya melatarbelakangi perencanaan kawasan ekowisata di Tano Ponggol. Perencanaan ini ditunjang pula dengan kondisi geografis Tano Ponggol yang berkontur. Sehingga perencanaan yang dilakukan masih dalam koridor berbasis konteks alam kawasan.

Oleh karena Tano Ponggol terdiri dari sebuah kanal dan jembatan, pengembangan ekowisata di Tano Ponggol dapat direncanakan dengan melakukan penataan ruang tepi air. Pada saat ini belum ada penataan yang signifikan terhadap pengaturan fisik dan aktivitas di lokasi tersebut. Kanal belum bisa dilalui kapal, pinggiran kanal ditumbuhi tumbuhan liar yang tidak tertata, dan jembatan penghubung dibangun hanya dengan pendekatan fungsional tanpa memperhatikan aspek visual. Hal ini menyebabkan terjadinya degradasi kualitas ruang di Tano Ponggol. Tano Ponggol yang memiliki potensi alam menjadi daerah wisata, saat ini hanya digunakan sebagai akses darat ke pulau Samosir saja. Oleh karena itu, penaatan ruang tepi air ini dilakukan dengan merevitalisasi kawasan tersebut melalui penyuntikan beberapa fungsi baru kawasan yang menunjang terbentuknya sebuah kawasan ekowisata. Pada akhirnya perencanaan yang dilakukan di Tano Ponggol merupakan pengembangan kawasan ekowisata tepi air di area Geopark.

\section{Permasalahan Utama Perancangan}

Permasalahan utama pada perancangan ini adalah sebagai berikut :

- Belum adanya penataan yang serius dalam mengembangkan Tano Ponggol menjadi sebuah kawasan ekowisata, baik dari pemerintah setempat maupun dari masyarakat setempat.

- Terjadinya degradasi kualitas ruang di tano Ponggol dan tidak terbentuknya makna kawasan sebagai sebuah kawasan ekowisata seperti yang telah direncanakan.

- Tidak ada fungsi yang memfasilitasi aktivitas sosial, ekonomi, budaya masyarakat setempat.

\section{Tujuan Penelitian}

Penelitian ini bertujuan untuk:

- Mendukung pemerintah dalam mengembangan kawasan ekowisata di Tano Ponggol.

- Memberikan pengetahuan dan pemahaman mengenai pengembangan kawasan ekowisata di sebuah area Geopark.

- Memberikan pedoman perencanaan pengembangan kawasan ekowisata melalui penataan ruang tepi akhir, dalam hal ini studi kasus yang diambil adalah Tano Ponggol.

\section{Kajian Teori}

\subsection{Kajian Teori Perencanaan Kawasan Pariwisata}

Edward Inskeep [7] dalam bukunya Tourism Planning menyatakan bahwa perencanaan sebuah fasilitas pariwisata membutuhkan komponen-komponen seperti berikut:

- Atraksi dan aktivitas wisatawan

- Akomodasi

- Fasilitas dan service bagi wisatawan 
- Fasilitas transportasi

- Infrastruktur

- Elemen Institusi

Atraksi dan aktivitas berupa pemanfaatan aset seperti alam, bangunan, dan budaya yang memiliki nilai tertentu sebagai daya tarik kawasan. Akomodasi berhubungan dengan penyediaan hotel dan penginapan di lokasi-lokasi yang strategis. Fasilitas dan servis bagi wisatawan berhubungan dengan fungsi komersil seperti restoran, retail penjualan souvenir, dan penyediaan fasilitas pelayanan publik seperti penyediaan barang-barang kebutuhan sehari-hari, perangkat keamanan, toilet, tempat ibadah, fasilitas kesehatan, dan lain-lain. Fasilitas transportsi berhubungan dengan sistem transportasi baik darat, air, dan udara, yang disediakan untuk menghubungkan antar kawasan wisata dan menghubungkan antara kawasan wisata dengan kawasan sekitarnya. Infrastruktur berhubungan dengan jaringan jalan yang baik, instalasi air bersih, sistem drainase, dan lain-lain. Fasilitas transportasi dan infrastruktur berhubungan dengan aksesibilitas. Terakhir, elemen Institusi berhubungan dengan penyediaan lembaga yang berperan aktif dalam mengelola segala aktivitas yang berhubungan dengan pariwisata di kawasan tersebut.

\subsection{Kajian Teori Perencanaan Kawasan Ekowisata}

Dalam Peraturan Menteri Dalam Negeri Nomor 33 Tahun 2009 [1] tentang Pedoman Pengembangan Ekowisata di Daerah, ekowisata merupakan kegiatan wisata alam di daerah yang bertanggungjawab dengan memperhatikan unsur pendidikan, pemahaman, dan dukungan terhadap usaha-usaha konservasi sumber daya alam, serta peningkatan pendapatan masyarakat lokal. Menyatakan terdapat lima prinsip dasar ekowisata, yaitu:

- Berbasiskan alam (berbasiskan lingkungan alami dengan fokus terhadap keunikan biologis, fisik atau budaya);

- Ekologi berkelanjutan;

- Pendidikan lingkungan (environmentally educative);

- Keuntungan lokal;

- Memberikan kepuasan terhadap pengunjung.

Ekowisata memiliki tujuh komponen [10], yaitu:

- Berkontribusi terhadap konservasi biodiversitas,

- Menyokong kesejahteraan masyarakat lokal,

- Memberikan pengalaman interpretasi/pembelajaran,

- Melibatkan tindakan yang bertanggung jawab dari pihak wisatawan dan industri pariwisata,

- Mengembangkan usaha skala kecil,

- Membutuhkan konsumsi sumber daya tak terbarukan yang serendah mungkin,

- Menekankan pada peluang-peluang partisipasi, kepemilikan, dan usaha lokal, khususnya bagi masyarakat pedesaan.

Ekowisata memiliki sembilan prinsip [10], yaitu:

- Meminimalisir dampak negatif terhadap alam dan budaya yang dapat merusak tujuan ekowisata,

- Mengedukasi para wisatawan mengenai pentingnya konservasi,

- Menekankan pentingnya usaha yang bertanggung jawab, yang bekerja secara kooperatif dengan masyarakat dan otoritas lokal untuk memenuhi kebutuhan lokal dan memberikan manfaat konservasi,

- Mengarahkan pendapatan ke konservasi dan pengelolaan kawasan ekowisata yang alami dan dilindungi, menekankan perlunya zonasi pariwisata regional dan rencana manajemen wisatawan yang dirancang untuk kawasan ekowisata yang dijadwalkan menjadi destinasi ekologis/ramah lingkungan,

- Menekankan penggunaan garis-dasar lingkungan dan sosial, serta program pemantauan jangka panjang, untuk menilai dan meminimalisir dampak,

- Berusaha keras untuk memaksimalkan manfaat ekonomi bagi negara, bisnis lokal, dan masyarakat, khususnya yang tinggal di dalam dan berdekatan dengan kawasan ekowisata, 
- Berusaha memastikan bahwa pengembangan pariwisata tidak melampaui batas sosial dan lingkungan dari perubahan yang dapat diterima sebagaimana ditentukan oleh para peneliti bekerja sama dengan penduduk lokal,

- Bergantung pada infrastruktur yang telah dikembangkan selaras dengan lingkungan, meminimalkan penggunaan bahan bakar fosil, melestarikan tanaman lokal dan satwa liar, dan menyatu dengan konteks alam dan budaya.

\subsection{Kajian Teori Perencanaan Ruang Tepi Air}

Kawasan tepi air adalah area yang komunitasnya dibatasi oleh air yang dalam pengembangannya mampu memasukkan nilai manusia, yaitu kebutuhan terhadap ruang publik dan nilai alami [3]. Kawasan tepi air sebagai bagian kota yang memiliki potensi air baik berupa sungai, danau, laut, teluk, dan atau kanal yang secara geografis dan secara alami membentuk suatu batas peralihan antara daerah perairan dan tepian air [2]. Salah satu yang harus diperhatikan dalam pengembangan kawasan tepi air adalah kawasan tepi air sebagai tempat berkumpulnya masyarakat dan memperbaiki kawasan ini dengan memperhatikan masalah tata guna lahan, zonasi, keselamatan, dan sirkulasi tepi air ini harus mampu mengakomodasi aktivitas masyarakat dimana wisatawan dapat belajar dan mengenal nilai-nilai kebudayaan masyarakat setempat.

Kawasan tepi air yang berhasil memiliki beberapa elemen penting yaitu :

- Tema, menentukan tema yang tepat sesuai karakter dan konteks kawasan yang kemudian dapat membentuk opini untuk menarik manusia ke kawasan tepi air ini,

- Image, membentuk identitas kawasan yang dapat merangsang persepsi positif wisatawan terhadap kawasan tepi air tersebut,

- Keaslian, perencanaan dilakukan secara kontekstual sesuai kearifan lokal.

- Fungsi, menciptakan fungsi yang unik dan menyediakan pengalaman positif di dalam fungsi-fungsi tersebut untuk mendukung keberhasilan ruang tepi air tersebut.

Dalam penataan ruang tepi air, terdapat dua aspek penting yang mendasari pengambilan keputusan untuk menghasilkan solusi [5][6], yaitu:

- Lokasi geografis, meliputi kondisi geografis dan iklim

- Konteks kawasan, meliputi pengguna yang berhubungan dengan rasa keterikatan terhadap

- kawasan, sejarah dan budaya, akses dan sirkulasi, dan karakter visual yang berhubungan dengan ciri fisik kawasan tepi air tersebut baik berupa bentuk, material, vegetasi, atau aktivitas yang khas. Dalam perancangan wisata kota tepi air terdapat beberapa kriteria yang harus diperhatikan [7] :

- Lokasi hotel dan fasilitas akomodasi wisata lainnya berada di daerah yang strategis,

- Akses ke tempat atraksi wisata dapat dicapai dengan jalan kaki dan transportasi yang nyaman dan mudah,

- Jalur Pedestrian yang menunjang yang dilengkapi street furniture yang memadai,

- Menata danau sebagai waterfront dengan meletakkan fasilitas komersil dan jalur pejalan kaki yang berorientasi ke tepian air,

- Mengatur perancangan kota yang baik dengan mengontrol batas ketinggian bangunan untuk mempertahankan batas pandangan dan koridor yang terbentuk

- Mengatur atraksi wisata dalam suatu kemasan yang dimaksud untuk mengontrol kebutuhan dan alur pengunjung

- Memperbaiki utilitas kawasan dan pusat informasi yang baik

\subsection{Kajian Teori Revitalisasi Kawasan}

Revitalisasi sebuah kawasan dapat dilakukan dengan melakukan intervensi fisik dan intervensi nonfisik. Intervensi fisik dapat dilakukan dengan memperbaiki dan meningkatkan kondisi fisik kawasan. Intervensi nonfisik dapat dilakukan dengan rehabilitasi aktivitas ekonomi dan rehabilitasi aktivitas sosial. Rehabilitasi aktivitas ekonomi dilakukan denganmenciptakan sebuah fungsi baru yang dapat menciptakan peningkatan ekonomi. Rehabilitasi aktivitas sosial dilakukan dengan cara menciptakan sebuah fungsi baru yang dapat merangsang terjalinnya interaksi sosial yang aktif. Fungsi-fungsi ini direncanakan untuk menciptakan sebuah aktivitas yang dapat merangsang vitalitas kawasan. 
Pemberian label (branding) pada suatu kawasan sering digunakan untuk menghidupkan kembali kawasan mati/rusak. Slogan seperti creative city, green city, dapat meningkatkan kualitas sebuah kawasan. Perubahan fungsi atau aktivitas yang sesuai dengan tema dapat diterapkan pada kawasan (functional restructuring) untuk mendukung konsep branding kawasan, atau dalam hal ini pada lingkungan fisik dan aktivitas masyarakat setempat. Pertumbuhan ekonomi dapat timbul dari perubahan fungsi atau aktivitas yang baru menggantikan aktivitas yang lama. Selain itu, salah satu aktivitas yang dapat menciptakan vitalitas sebuah ruang adalah aktivitas pejalan kaki/pedestrian. Vitalitas sebuah kawasan bergantung pada interaksi yang dilakukan melalui aktivitas pedestrian [8]. Maka dari itu, sirkulasi di dalam kawasan harus direncanakan permeable dan legible untuk memaksimalkan interaksi yang terjadi didalamnya.

\subsection{Kriteria Penataan Ruang Tepi Air Untuk Pengembangan Kawasan Eko Wisata di Kawasan Geopark}

Berdasarkan kajian teori diatas, kriteria penataan ruang tepi air untuk pengembangan kawasan ekowisata di Tano Ponggol adalah:

- Penataan ruang tepi air harus sesuai dengan konteks geografis Kawasan,

- Penataan ruang tepi air harus memperhatikan konservasi biodiversitas,

- Penataan ruang tepi air harus memberikan pengetahuan/pendidikan kepada wisatawan mengenai kondisi geografis, sosial dan budaya kawasan,

- Penataan fisik ruang tepi air harus dilakukan dengan konsep berkelanjutan secara ekologis untuk meminimalisir dampak negatif terhadap alam yang dapat merusak terwujudnya pengembangan kawasan ekowisata ini,

- Seluruh kawasan ekowisata tepi air harus bisa diakses para pedestrian dan sistem transportasi dengan mudah dan nyaman serta dilengkapi dengan street furniture yang baik,

- Penyuntikan fungsi komersil untuk mengembangkan usaha skala kecil harus dilakukan. Aktivitas komersil ini bertujuan untuk meningkatkan ekonomi lokal sehingga masyarakat setempat menjadi sejahtera,

- Fungsi komersil dan jalur pedestrian harus berorientasi ke tepian air,

- Pembentukan ruang publik untuk mengakomodasi aktivitas-aktivitas ekonomi, sosial, dan budaya yang dapat merangsang peluang-peluang partisipasi masyarakat setempat.

- Pembentukan tema dan image kawasan yang ditampilkan melalui kondisi fisik dan aktivitas harus dapat meningkatkan kualitas kawasan dan menguatkan karakter geografis kawasan sehingga menciptakan makna kawasan yang positif untuk memberikan kenyamanan dan kepuasan.

- Penataan fisik dan aktivitas ruang tepi air harus memberikan wisatawan pengalaman dalam memahami konteks lokasi.

- Sumberdaya yang digunakan bersifat keberlanjutan untuk meminimalisir kerusakan lingkungan fisik kawasan.

- Edukasi mengenai tanggungjawab wisatawan dan industri pariwisata dalam menjaga kelestarian (konservasi) warisan geologi harus dilakukan.

- Pengembangan infrastruktur selaras dengan lingkungan, tidak merusak kondisi fisik kawasan, meminimalisir penggunaan bahan bakar fosil, melestarikan tanaman lokal dan satwa liar, dan menyatu dengan konteks alam dan budaya. Jaringan infrastruktur ini harus direncanakan tidak hanya bersifat fungsional tetapi juga harus memberikan sebuah karakter visual yang positif.

- Kawasan harus memiliki sistem transportasi yang terintegrasi di dalam kawasan ekowisata, baik air maupun darat, sehingga setiap titik ekowisata dapat mudah diakses oleh wisatawan. Hal ini untuk menarik banyak wisatawan datang ke dalam kawasan.

- Kawasan ekowisata harus dapat menyediakan akomodasi tempat tinggal di lokasi yang strategis

\section{Studi Preseden: Kawasan Geopark Batu Vulkanik Sai Kung Waterfront, Hongkong}

Sai Kung memberikan pelayanan ekowisata yang baik bagi wisatawan yang berencana menjelajahi kawasan Geopark. Sai Kung berkembang menjadi sebuah kawasan wisata dengan mempertahankan lingkungan fisik dan budayanya. Sai Kung menyediakan aktivitas atraktif yang menjadi daya tarik, yaitu penjelajahan batu vulkanik yang dilakukan dengan perahu, kayak, dan kapal apabila dari air, dan berjalan kaki di atas gertak yang dibangun di bagian 
tepi airnya. Ruang tepi airnya mengakomodasi berbagai aktivitas ekonomi, sosial, dan budaya. Banyak restoran, bar, dan tempat acara yang bisa menarik wisatawan lokal dan mancanegara untuk datang ke kawasan tersebut. Pada Sai Kung juga terdapat ruang-ruang publik dimana komunitas-komunitas masyarakat bertemu. Perpaduan lingkungan fisik Geopark yang di konservasi dan aktivitas sosial ekonomi yang berkembang, Sai Kung menjadi salah satu kawasan wisata yang vital di Hongkong meskipun memiliki image sebagai daerah yang tua (gambar 1).
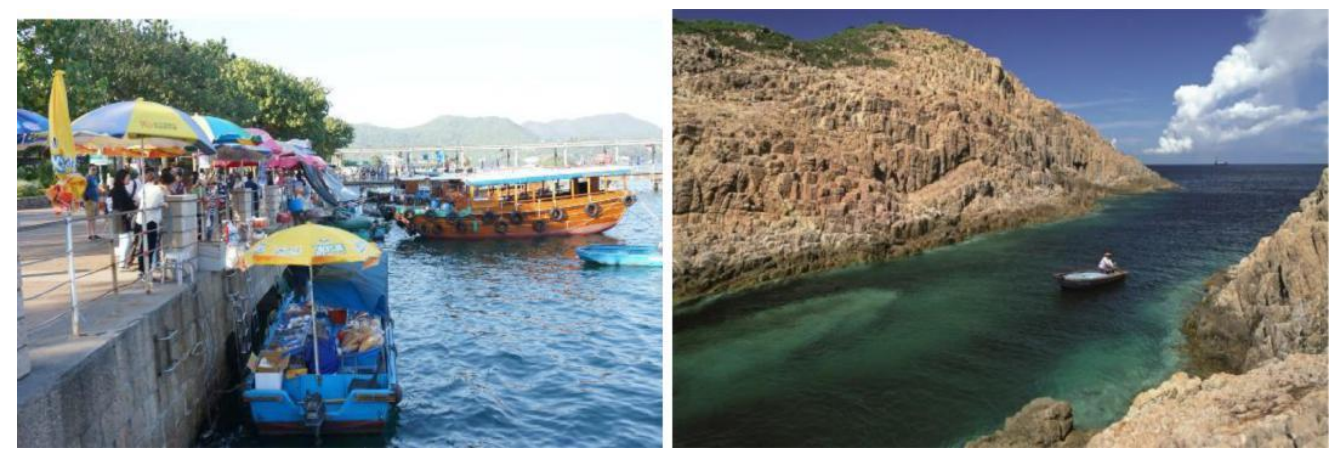

Gambar 1.. Kawasan Wisata Sai Kung

Sumber: https://www.google.com/

\section{Analisa Lokasi}

Batasan tapak dalam studi ini mencakup kawasan tepi air Tano Ponggol sepanjang $\pm 1,7 \mathrm{Km}$ dengan mengambil bagian kanan-kiri kanal selebar 30 Meter sesuai Permen PUPR NOMOR 28/PRT/M/2015 mengenai Garis Sempadan Sungai dan Garis Sempadan Danau [4].

Terjadi degradasi kualitas pada ruang tepi air Tano Ponggol disebabkan oleh:

- Kondisi fisik kawasan tidak memiliki kualitas visual yang baik

- Tidak terlihat adanya aktivitas sosial, ekonomi, dan budaya.

- Alur pergerakan di dominasi oleh sistem transportasi mobil dan angkutan umum.

- Pola penataan ruang tepi air di Tano Ponggol belum sesuai peraturan daerah dan budaya masyarakat setempat.

- Jumlah RTH yang terdapat di kota Pangururan tidak sesuai dengan yang telah ditentukan didalam peraturan daerah, yaitu dibawah $30 \%$.

- Pola penataan RT H pada ruang tepi air di Tano Ponggol belum sesuai dengan kondisi fisik kawasan,

- Masyarakatnya memiliki mata pencaharian yang serasi dengan kondisi alam Tano Ponggol, yaitu, bertani, berkebun dan berladang, beternak, dan mengelola tambak. Namun, sebagian lahan belum

- digunakan secara maksimal oleh masyarakat sehingga lahan kosong tersebut ditumbuhi tanaman liar.

- Area komersil tidak direncanakan dengan baik sehingga tidak dapat mengakomodasi aktivitas ekonomi sebagian kecil masyarakat yang memiliki mata pencaharian sebagai pedagang dan membuat tata daerah Tano Ponggol menjadi tidak teratur dengan adanya fungsi pasar yang tidak sesuai dengan peraturan daerah.

- Tidak terdapat ruang publik yang cukup. Belum adanya fungsi kawasan yang dapat membentuk sebuah ruang publik yang baik.

- Tidak tercipta harmonisasi kebudayaan masyarakat dengan kondisi geografisnya.

- Arsitektur bangunan di Tano Ponggol didominasi dengan langgam rumah tradisional Batak Toba. Gaya bangunan ini berpotensi memberikan sebuah karakter kawasan yang dapat berkontribusi dalam keberhasilan kawasan ekowisata di Tano Ponggol. Saat ini kondisi permukiman tradisional tersebut banyak mengalami kerusakan dan sebagian rumah disewakan sehingga fisik bangunan banyak berubah dari bentukan aslinya. Solusi yang diberikan adalah melakukan konservasi langgam bangunan sehingga bentuk aslinya tetap dipertahankan dan digunakan (gambar 2). 

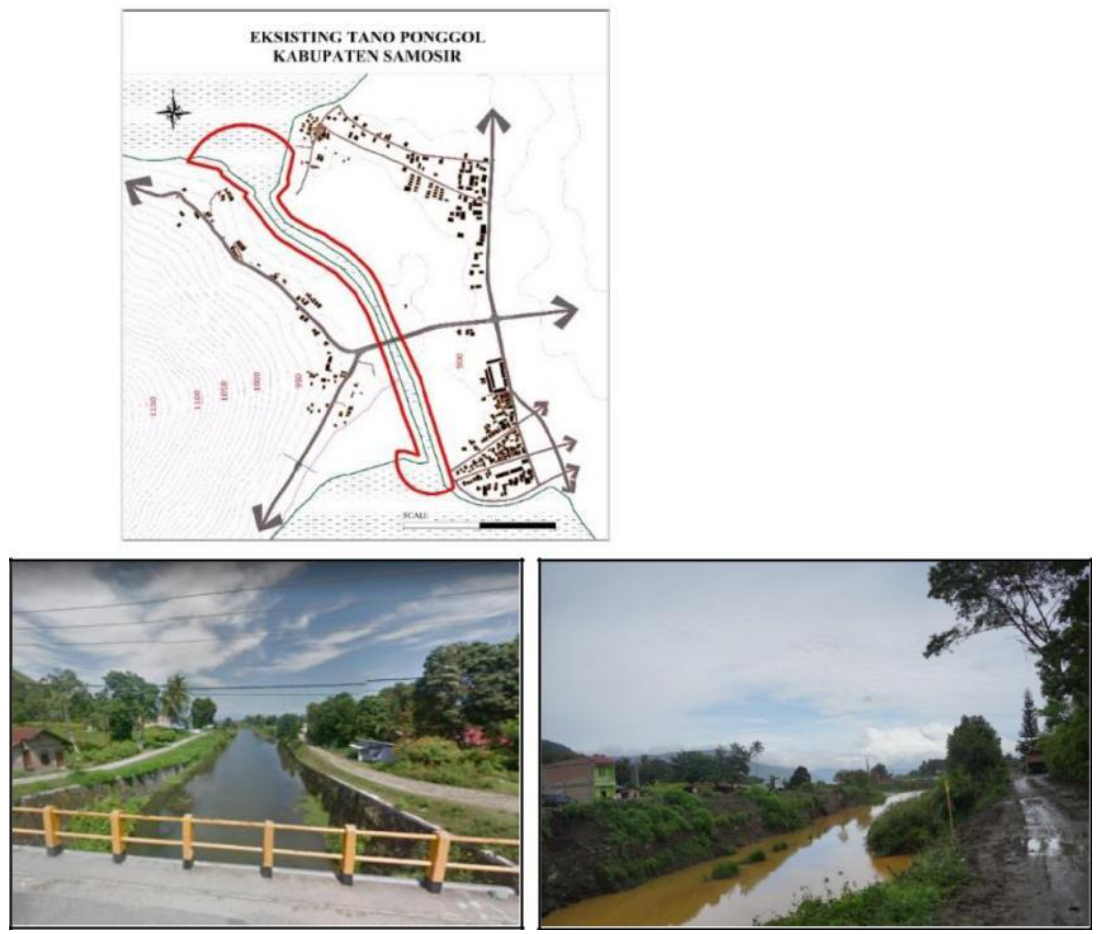

Gambar 2. Bagian yang ditandai dengan warna merah merupakan lokasi perencanaan.(atas) Kanal dan Jembatan Tano Ponggol dimana area pinggiran kanal tidak ditata sesuai dengan arah (bawah) perkembangan Sumber: https://www.google.com/

Dalam bab Kebijakan dan strategi di RDTR Kawasan Perkotaan Pangururan Tahun 2007-2017 [9], Kawasan Tano Ponggol diberikan kebijakan untuk di konversi dan direvitalisasi dengan strategi sebagai berikut:

- Mengkonversi fungsi kawasan Tano Ponggol sebagai kawasan bersejarah dan objek daya tarik wisata.

- Dikembangkan sebagai Kawasan Unggulan di Kawasan Perkotaan Pangururan.

- Mengkonversi dan merevitalisasi kawasan permukiman di Kawasan Tano Ponggol menjadi Pintu Utama (Main Entrance) Kawasan Perkotaan Pangururan sekaligus Entrance Pulau Samosir (perbatasan Pulau Sumatera dengan PulauSamosir).

- Meningkatkan fungsi air Danau Toba di Kawasan Tano Ponggol dengan melakukan pengerukan agar dapat dilalui kapal-kapal pengangkut barang dan penumpang baik yang bersifat jalur pelayaran regional maupun lokal. yaitu:

Menurut pengamatan dan melalui analisa data, Tano Ponggol memiliki beberapa potensi untuk dikembangkan,

- Arah pengembangan kawasan yang tertulis di dalam RDTR Kawasan Perkotaan Pangururan Tahun 2007-2017 menjadi kawasan yang akan diunggulkan di didalam kecamatan Pangururan, yaitu sebagai pusat pariwisata dan perdagangan dan jasa.

- Jembatan di Tano Ponggol merupakan gerbang utama jalur darat menuju pulau Samosir. Jembatan ini memiliki potensi yang besar untuk menjadi kawasan wisata yang atraktif bagi masyarakat setempat maupun pendatang dari luar pulau Samosir.

- Tano Ponggol memiliki potensi sebagai jalur lintas transportasi air apabila dilakukan pelebaran kanal, yang saat ini memiliki lebar $\pm 32 \mathrm{~m}$ dan panjang $\pm 1200 \mathrm{~m}$, sesuai dengan rencana awal Belanda membangun kanal tersebut.

- Arsitektur bangunan di Tano Ponggol didominasi dengan langgam rumah tradisional Batak Toba. Gaya bangunan ini berpotensi memberikan sebuah karakter kawasan yang dapat berkontribusi dalam keberhasilan kawasan ekowisata di Tano Ponggol. Saat ini kondisi permukiman tradisional tersebut banyak mengalami kerusakan dan sebagian rumah disewakan sehingga fisik bangunan banyak berubah dari bentukan aslinya. Solusi yang diberikan adalah melakukan konservasi langgam bangunan sehingga bentuk aslinya tetap dipertahankan dan digunakan. 
- Ruang Publik saat ini berupa taman di pinggir Danau Toba di depan rumah dinas bupati. Masyarakat berkumpul dan berinteraksi di taman ini. pada area ini juga terdapat beberapa pedagang kaki lima yang berjualan makanan. Aktivitas ini dapat diakomodasi di ruang tepi air untuk menarik turis datang untuk berinteraksi dengan masyarakat setempat.

- Sudah banyaknya penginapan di sekitar Tano Ponggol yang dapat menunjang kawasan Ekowisata tepi air ini.

\section{Kriteria Penataan Ruang Tepi Air Untuk Pengembangan Kawasan Ekowisata Di Tano Ponggol}

Kriteria Penataan Ruang Tepi Air Untuk Pengembangan Kawasan Ekowisata Di Tano Ponggol, yaitu:

- Penataan fisik ruang tepi air harus memperhatikan konservasi biodiversitas, menggunakan sumber daya yang berkelanjutan, dan dilakukan pula dengan konsep berkelanjutan secara ekologis tanpa melakukan pembongkaran berskala besar untuk meminimalisir dampak negatif terhadap alam.

- Penataan ruang tepi air harus bersifat edukatif dengan memberikan pengetahuan/pendidikan kepada wisatawan mengenai kondisi geografis, sosial dan budaya kawasan Tano Ponggol,

- Aktivitas utama kawasan adalah berjalan kaki mengelilingi ruang tepi air dengan sequence ruang yang akan memberikan serial vision yang menarik dan tidak membosankan,

- Aksesibilitas kawasan ekowisata tepi air direncanakan mudah bagi pedestrian dengan sistem jalur yang permeable (alur pergerakan yang mengalir ke seluruh ruang tepi air yang direncanakan) dan legible (alur yang mudah dibaca dan tidak rumit),

- Jalur pedestrian harus dilengkapi dengan street Furniture yang baik,

- Aksesibilitas sistem transportasi dipermudah dengan pembangunan sistem infrastruktur yang

- baik,

- Aktivitas komersil harus disuntik untuk mengembangkan usaha skala kecil sehingga masyarakat setempat dapat hidup sejahtera dengan peningkatan ekonomi yang baik,

- Fungsi komersil dan jalur pedestrian harus berorientasi ke tepian air,

- Ruang publik- untuk mengakomodasi aktivitas-aktivitas ekonomi, sosial, dan budaya yang dapat merangsang peluang-peluang partisipasi masyarakat setempat- direncanakan hanya bisa diakses melalui sistem transportasi air dan melalui aktivitas berjalan kaki.

- Ruang public harus melebur dengan jalur pedestrian.

- Pembentukan tema dan image kawasan yang ditampilkan melalui kondisi fisik dan aktivitas harus dapat meningkatkan kualitas kawasan dan menguatkan karakter geografis kawasan sehingga menciptakan makna kawasan yang positif untuk memberikan kenyamanan dan kepuasan dan memberikan wisatawan pengalaman dalam memahami konteks lokasi,

- Lembaga yang bertanggungjawab mengelola kawasan ekowisata harus dibentuk salah satunya untuk berfungsi mengedukasi mengenai tanggungjawab wisatawan dan industri pariwisata dalam menjaga kelestarian (konservasi) warisan geologi harus dilakukan.

- Pengembangan infrastruktur selaras dengan lingkungan, tidak merusak kondisi fisik kawasan, meminimalisir penggunaan bahan bakar fosil, melestarikan tanaman lokal dan satwa liar, dan menyatu dengan konteks alam dan budaya.

- Jaringan infrastruktur harus direncanakan tidak hanya bersifat fungsional tetapi juga harus memberikan sebuah karakter visual yang positif.

- Kawasan harus memiliki sistem transportasi yang terintegrasi di dalam kawasan ekowisata Tano Ponggol, baik air maupun darat, sehingga setiap titik ekowisata dapat mudah diakses oleh wisatawan.

- Kawasan ekowisata Tano Ponggol akan bekerja sama dengan kawasan sekitarnya di dalam Kabupaten Samosir menyediakan akomodasi tempat tinggal mengingat kawasan Kabupaten Samosir tidak besar sehingga jarak tempuh dari satu kawasan wisata ke kawasan waisata lain tidak jauh.

- Konservasi rumah adat Batak Toba harus dilakukan. 


\section{Konsep dan Simulasi Desain}

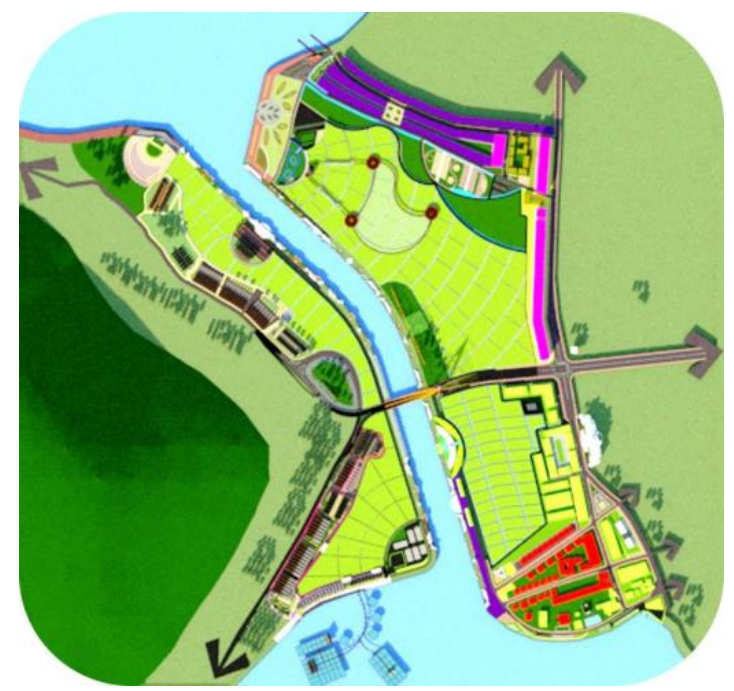

Gambar .3. Rencana Penataan Ruang Tepi Air untuk Pengembangan Kawasan Ekowisata di Tano Ponggol Sumber: dok. pribadi

Pengembangan yang dilakukan bersifat harmonis dengan alam dengan mengikuti bentuk geografis kawasan sehingga pembongkaran yang dilakukan merupakan skala kecil namun memberikan dampak yang besar bagi kawasan untuk menjaga kelestarian warisan geologinya (gambar 3-4.).Tano Ponggol menjual tema aktivitas ekowisata untuk menciptakan image positif dengan menonjolkan potensi alamnya yang memiliki karakter geologi yang kuat, yaitu berada di danau toba yang berada di cekungan sebuah gunung merapi Toba dan berada di pulau Samosir yang merupakan kaldera dari letusan gunung tersebut puluhan ribu tahun lalu. (gambar 4)

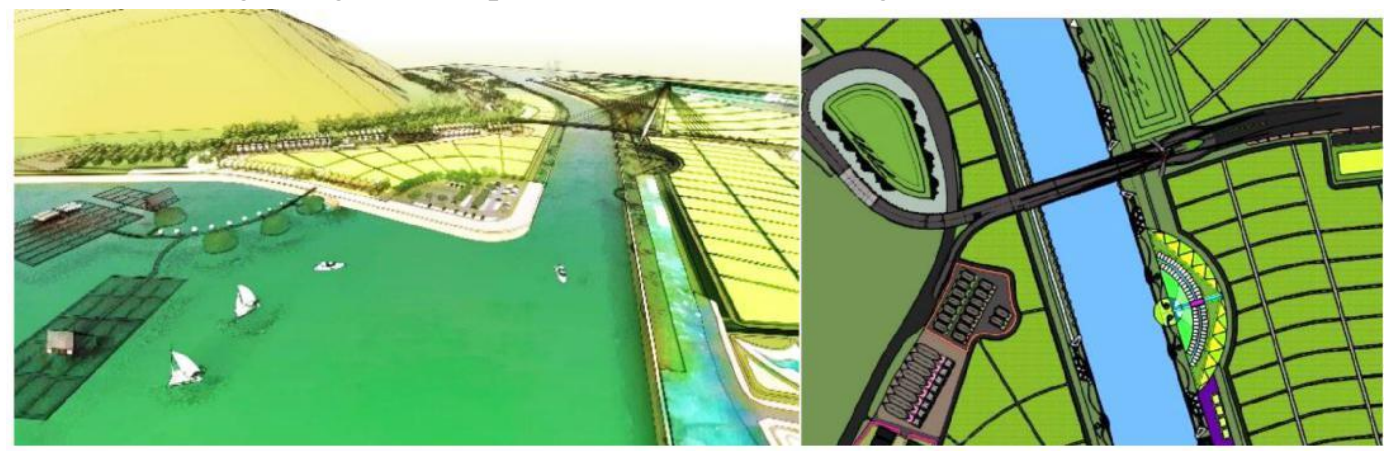

Gambar 4. Rencana Penataan Ruang Tepi Air Untuk Pengembangan Kawasan Ekowisata di Tano Ponggol Dengan Mengikuti Bentuk Geografis Kawasan Sumber: dok. pribadi

Kawasan ekowisata Tano Ponggol direncanakan berfungsi sebagai ruang publik baru yang mengakomodasi aktivitas ekonomi, sosial, dan budaya masyarakat setempat. Aktivitas ekonomi diciptakan dengan menyuntik fasilitas retail kerajinan dan souvenir setempat. Kawasan ini didesain permeable bagi pedestrian dan pesepeda dengan dilengkapi street furniture yang baik yang membuat kawasan ini legible. Pada tepian air dilengkapi dengan ruang terbuka hijau dan dermaga-dermaga kecil untuk menguatkan konsep ekowisata. Perencanaan harus berkonsep ekologi berkelanjutan dimana penempatan vegetasi mengikuti alur kontur dan memanfaatkan material lokal yang terdapat di Tano Ponggol (gambar .5.) 


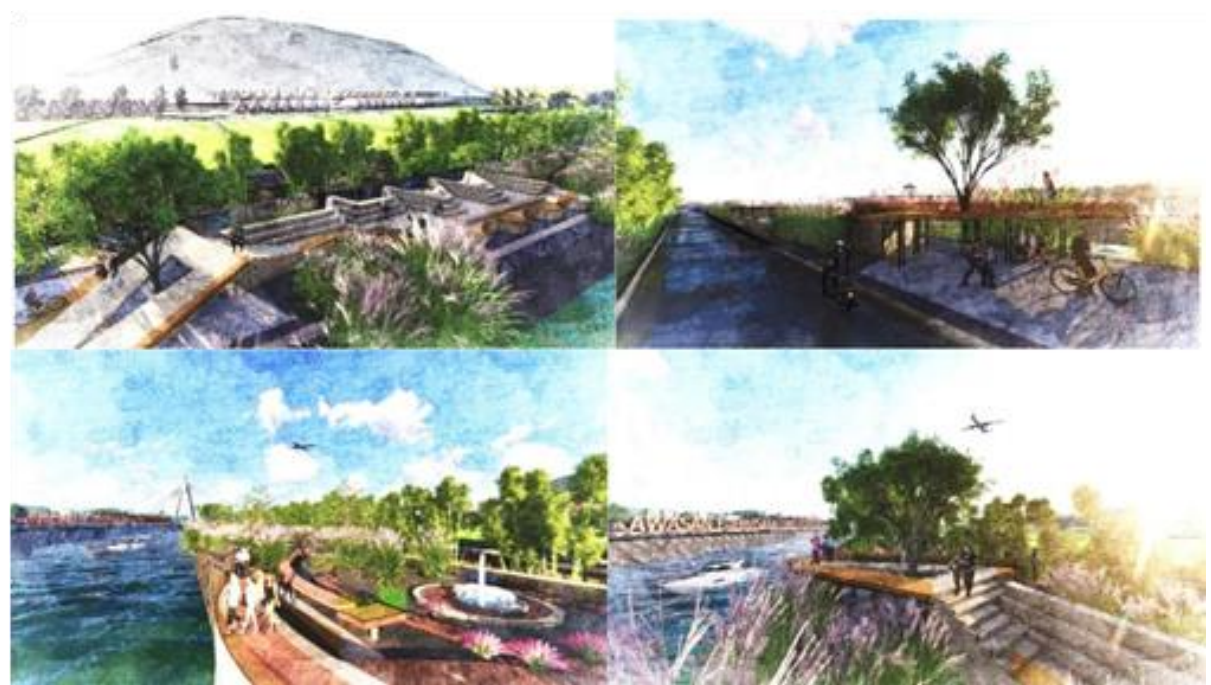

Fig.5. Ruang Publik pada Ruang Tepi Air Kawasan Ekowisata Tano Ponggol Sumber: dok. pribadi

Untuk membentuk karakter kawasan yang kuat dan menonjolkan budaya masyarakat setempat, layout ruang public pada ruang tepi air Tano ponggol didesain mengadopsi bentuk Gorga Batak (gambar 6) Ini sebagai apresiasi terhadap budaya lokal. Bentukan ini diharapkan dapat memberikan pengalaman ruang yang unik pada kawasan.

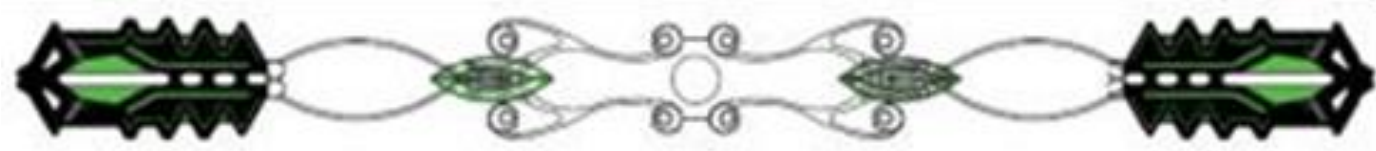

Gambar 6. Layout Ruang Publik pada Ruang Tepi Air Kawasan Ekowisata Tano Ponggol Sumber: dok. pribadi

Kanal Tano ponggol direncanakan mengalami pelebaran bisa dilalui kapal, baik kapal angkut barang maupun kapan pesiar untuk wisatawan. Perjalanan melalui kapal ini juga berfungsi sebagai program wisata air yang atraktif di kawasan ekowisata Tano Ponggol dan untuk meningkatkan aktivitas ekonomi masyarakat setempat (gambar 7). Pada beberapa titik kawasan direncanakan dermaga-dermaga kecil yang tersebar di seluruh kabupaten Samosir untuk mengakomodasi system transportasi air ini.

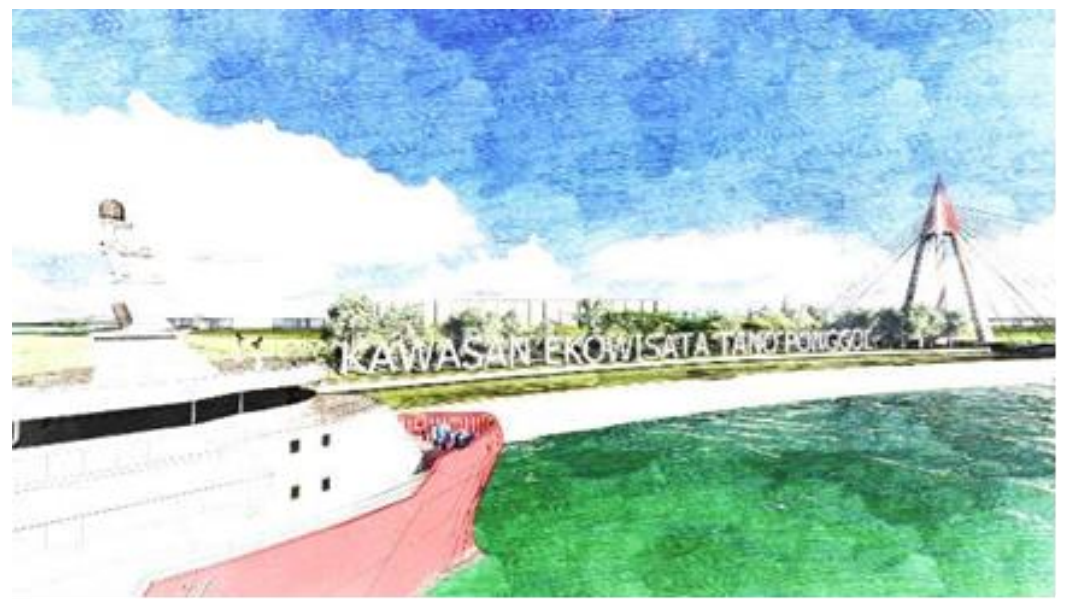

Gambar 7. Sistem Transportasi Air disediakan di Kanal Tano Ponggol Sumber: dok. pribadi 
Jembatan penghubung didesain tidak hanya berbasis fungsional tetapi juga mengakomodasi aktivitas ekowisata. Direncanakan menjadi sebuah landmark kawasan dengan desain yang menguatkan karakter kawasan (gambar 8)

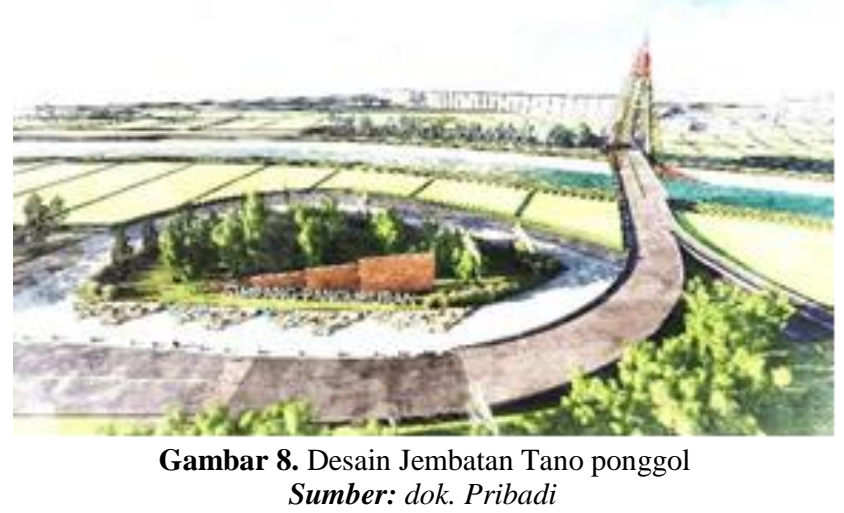

Bangunan adat Batak dikonservasi sebagai penguatan karakter kawasan yang berkomitmen tidak mengubah kondisi fisik kawasan sehingga image yang tercipta lebih kuat. (gambar 9)

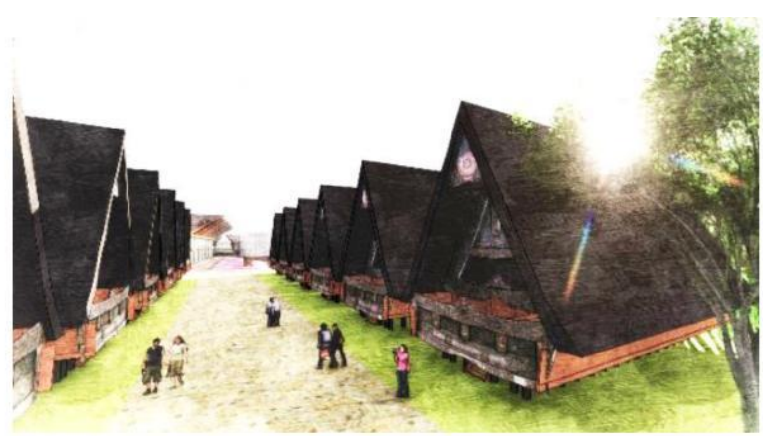

Gambar 9. Simulasi Konservasi Rumah Adat Batak Toba Sumber: dok. pribadi

Lahan dan sawah disekitar ruang tepi air dimanfaatkan sebagai menjadikannya objek wisata yang akan ditunjang dengan canopy trail sebagai daya tarik. (gambar 10-11)

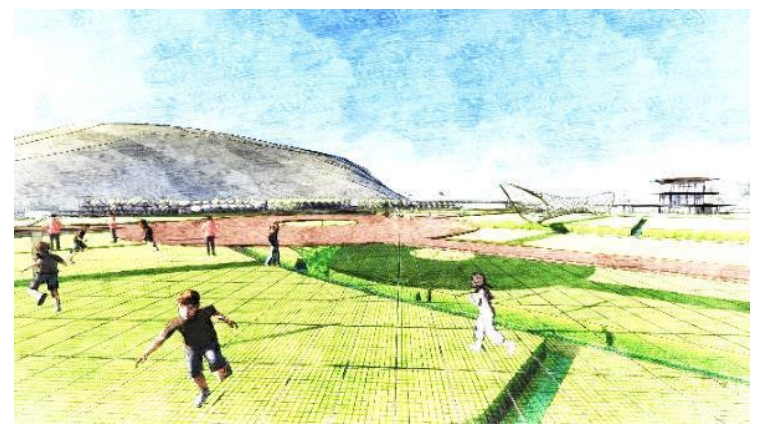

Gambar 10. Desain Sawah dengan Canopy Trail Sumber: dok. pribadi. 


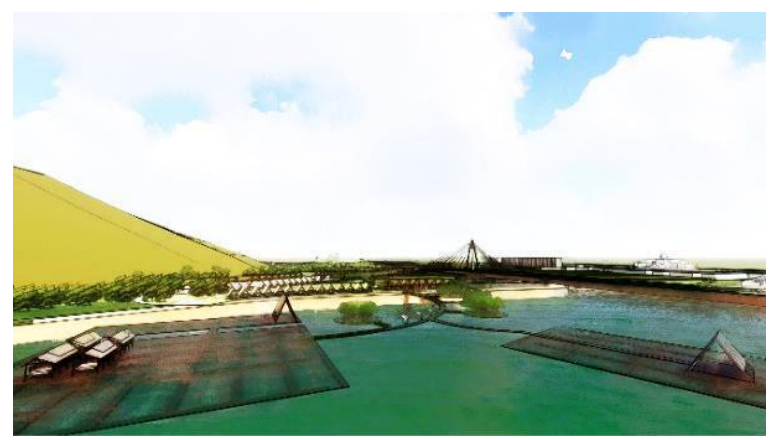

Gambar 11. Desain Pengelolaan Tambak sebagai salah satu aktivitas Ekonomi Sumber: dok. pribadi

\section{Kesimpulan}

Pengembangan kawasan ekowisata di Tanah Ponggol dapat dilakukan dengan penataan ruang tepi air dengan menyediakan ruang publik yang mengakomodasi aktivitas wisata, sosial, ekonomi, mitigasi, dan budaya, tanpa merubah warisan geologi secara signifikan.

Mengangkat potensi-potensi alam Tano Ponggol secara komprehensif dimana nilai luhur budaya sejalan dengan penguatan nilai ekonomi masyarakat dan pelestarian warisan geologi. Pengembangan kawasan ekowisata Tano Ponggol bersifat konservatif dengan memasukkan aktivitas-aktivitas pariwisata.

\section{Referensi}

[1] Peraturan Mentri PUPR Nomor 28/PRT/M/2015

[2] Breen, Ann dan Dick Rigby. (1994):Waterfront : Cities Reclaim Their Edge. McGraw Hill, Inc :USA.

[3] Carr, Stephen, dkk, (1992) : Public Space, Cambridge University Press, USA

[4] Peraturan Menteri Dalam Negeri Nomor 33 Tahun 2009

[5] Wood,M.E.,(2002): Ecotourism: Principles, Practices \& Policies for Sustainability. The International Ecotourism Society, Burlington.

[6] Wrenn, D. M., Casazza, J. A., \& Smart, J. E., (1983) : Urban Waterfront Development, The Urban Land Institute, Washington DC, 2-20.

[7] Inskeep, Edward. (1991). Tourism Planning: An Integrated and Sustainable Development Approach,New York: Van Nostrand Reinhold..

[8] Lewis, Sally, (2005): Front to Back: A Design Agenda for Urban Housing. Routledge, United Kingdom

[9] RDTR Kawasan Perkotaan Pangururan 2007-2017. Pemerintah Kabupaten Samosir

[10]Torre, L.Azeo, (1989) : Waterfront Development. Van Nostrand Reinhold Co, New York. 